\title{
Writing systems and linguistic identity of the Vlach community of Eastern Serbia
}

\author{
Monica Huțanu ${ }^{1,2 *}$, Annemarie Sorescu-Marinković ${ }^{3 *}$ \\ ${ }^{1}$ Faculty of Letters, History and Theology, West University, Bd. Vasile Pârvan 4, 300223 Timişoara, Romania \\ ${ }^{2}$ Faculty of Philology, University of Belgrade, Studentski Trg 3, 11000 Belgrad, Serbia \\ ${ }^{3}$ Institute for Balkan Studies, Serbian Academy of Sciences and Arts, Knez Mihailova 35/IV, 11000 Belgrade, Serbia
}

\section{Article info}

History:

Received August 29, 2017

Accepted October 2, 2017

Published November 30, 2017

Key words:

sociolinguistics

Vlachs of Eastern Serbia

ortography

\begin{abstract}
In this article we examine, from a predominantly sociolinguistic perspective, the writing systems created throughout time for the graphic rendering of the variety of Romanian spoken by the Vlachs of Eastern Serbia. We especially investigate what influences the choice of a script (Latin or Cyrillic), of orthographic conventions and of a writing system, and how this choice correlates with the ideological attitude (reintegrationist or independentist) of the proponents. To this end, we analyse the writing systems used for rendering the vernacular in "Vorba noastră", the first publication in the local variety (1945-1948), and the systems put forward in the last 20 years by the members of the community engaged in political and linguistic debates (Paun Es Durlić, Dragomir Dragić, Slavoljub Gacović, Ljubiša lu Boža Kići, the "Gergina" Association). The analysis and the comparison of the systems attest to the importance of the ideological, social and political factors in creating and imposing an orthography for an unwritten idiom.
\end{abstract}

\section{Preliminaries}

Creating, imposing or reforming a writing system for an idiom is never a neutral, aseptic and conflictfree enterprise. Proof of this are, in the case of Romanian, the numerous controversies regarding the introduction of the Latin script in the $18^{\text {th }}$ and $19^{\text {th }}$ centuries or the endless disputes and revolts stirred by the reintroduction of the grapheme $<\hat{\mathrm{a}}>$ in 1993. Defining orthography as mere convention proves therefore insufficient; a writing system does not only graphically render the elements of speech or is used to decode a written message, but is always ideologically charged.

The ideology (or, more commonly, competing ideologies) behind choosing a particular script is even more obvious in the case of a still unwritten idiom. The choice a particular community makes regarding the way they will visually represent their language also implies a decision on how they will represent their identity (Unseth, 2008, p. 1), not only within the community, but also at a national or international level. Analysing the writing systems proposed for the vernacular of Haiti (kreyòl), Schieffelin \& Doucet (1994) note that they are not based on a scientific investigation of the linguistic facts, but are cultural products which (re)present the Haitian postcolonial identity in different ways (closer or further from the French one), according to certain social and political interests of the competing groups and ideologies. Moreover, this priority given to social, political or religious facts over purely linguistic, functional ones is well documented for the graphic systems created by and for diverse communities and idioms, such as Hmong (Eira, 1998), Selsq (Priestly, 1992), Guernesiais (Sallabank, 2002). Through a process of iconization (Irvine \& Gal, 2000; Sebba, 2015), of transforming the conventional relationship into a symbolic one, the graphic systems become an expression of the community's identity (Unseth, 2005, p. 20), emblems (Coulmas,

*Email addresses: monica.hutanu@e-uvt.ro (MH), annemariesorescu@gmail.com (ASM). 
Monica Huțanu, Annemarie Sorescu-Marinković

2009, p. 15) or symbols of identity (Eira, 1998, p. 172), having not only a linguistic, but also a social meaning.

In this paper we will analyse, from a sociolinguistic perspective, the writing systems developed over time by and for the Vlach community of Eastern Serbia. The Vlachs speak an archaic variety of the Romanian language, which has been for more than a century left outside the influence of standard Romanian. Our intention is not so much to assess the validity of these orthographic solutions or to make value judgments, but rather to understand what influences the choice of a particular writing system, how the spelling choices are justified and how the preference for a particular graphic representation correlates with the ideological position of its proponents.

\section{The Vlach community of Eastern Serbia. Linguistic and sociolinguistic features}

The region south of the Danube in Serbia, along the rivers Timok, Mlava, Morava and Pek, is inhabited by a mostly rural community, generally bilingual, with a multiple, contextual identity, whose members speak both an archaic variety of Romanian (as their mother tongue), and Serbian (as the official language). According to most researchers, the history of the community goes back to the $18^{\text {th }}-19^{\text {th }}$ centuries, when migrations from the Romanian provinces of Wallachia and Banat took place (Constante, 1929; Metes, 1971; Weigand, 1900). Large scale migrations were recorded especially between 1718 and 1739, after the war between the Austrian and the Ottoman Empire, when Eastern Serbia was part of the Timişoara district, run by Count Mercy. After this date, the migrations continued, but at a lower intensity, and were mainly spontaneous. The persistence in the area of an autochtonous Romanized population-a hypothesis put forth by several researchers (e.g., Popovici, 1919) and supported by some community members - remains difficult to prove, and does not exclude the theory of successive migrations.

The split identity, between loyalty to the Serbian state and the "ethnic instinct" (Vâlsan, 1913, p. 343), is obvious in the data from the most recent Serbian census (2011), which shows that 35330 people declared Vlach ethnicity, but as much as 43095 claimed they spoke Vlach as their mother tongue (in other words, more than 7000 people who speak Vlach declared themselves (probably) Serbs). The ethnonyms used by the community members also reflect this dual identity: rumin, when they use their mother tongue, $v l a h$, when they speak Serbian. However, nowadays some of the community members prefer to use the terms vlah and vla (fem. vlaina) in their vernacular as well; by adopting the exonym, the name given by "outsiders", they explicitly reject any connection with the Romanian identity. That is why, in Romanian we prefer the term "Rumanophone community" (also used by Sorescu-Marinković, 2007; Sikimić, 2014; Florea, 2015), and not Romanians from the Timok Valley or Timok Romanians ${ }^{1}$, widely used in the Romanian public and academic discourse, while in English we employ the commonly used term "Vlach community".

From a strictly linguistic point of view, the idioms spoken by the Vlachs can be considered an archaic, uneven variety of Romanian, made up of four dialectal groups: țărani, ungureni, munteni and bufani. The first researchers of the community have already noticed that the vernacular spoken by the țärani is closely linked to the Muntean dialect of the Romanian language, while that of the ungureni has common elements with the Banat dialect (Constante, 1929; Pătruț, 1942; Petrovici, 1942). Recent research adds two more dialectal groups: the munteni (Durlić, 2011), who speak a transition idiom between that of the țărani and of ungureni, closer to the latter, and the bufani (Sorescu-Marinković, 2012a), today largely assimilated linguistically by the ungureni. As a result of the permanent contact with Serbian, the official, more prestigious state language, and of scarce contacts with standard Romanian, the idiom used by the Vlachs of Eastern Serbia is strongly influenced by Serbian, especially at the lexical level ${ }^{2}$.

\footnotetext{
${ }^{1}$ The term "Rumanophone communities" was first used to include all population groups that speak varieties of Romanian, without necessarily assuming a Romanian identity: Romanians from Vojvodina, Vlachs from Eastern Serbia, the Boyash across Serbia, the new Romanian diaspora etc.

${ }^{2}$ For a more detailed presentation of the community (location, size, origin, ethnographic and dialectal groups, occupa-
} 
The belief that their vernacular is either historically and linguistically subordinated to the Romanian language or completely independent from it divides the engaged members of the community into two opposing factions ${ }^{3}$, similar to those involved in the dispute on the relationship between Galician and Portuguese, from which we will borrow the terms designating the two groups (see Sebba, 2007, p. 126127; Salgado \& Monteagudo, 1993, p. 200-201). The "reintegrationists" (pro-Romanian) consider that their local idiom is a variety of Romanian, brought to Serbia through migration, while the differences can be accounted for by the fact that the neologisms in standard Romanian did not enter the vernacular (Dragić, 2007). On the other hand, the "differentionalists" or "independentists" (pro-Vlach) consider that the hybrid aspect of the vernacular (which is the result of lexical borrowings from Serbian and of frequent code switching) is a sufficient argument for considering it a separate language from Romanian, with no mutual intelligibility, for which one would need a translator, as one member of the community told us ${ }^{4}$. The independentists are in general supporters of the indigeneity theory and, though they might not necessarily be the most numerous, they are certainly the most visible. Nowadays (2017), they are the only ones politically represented in the Vlach National Council (VNC) $)^{5}$, which may give the impression of consensus on these issues within the community.

The plethora of statements, both extreme and moderate, of the last years points to the emergence of a new Vlach consciousness, opposed both to the Romanian and to the Serbian identity. Its by-products are the attempts at language planning and standardization (Huțanu \& Sorescu-Marinković, 2015), meant to turn Vlach into an Ausbau language (Kloss, 1967). Unlike Abstand languages (by 'distance'), different enough intrinsically from other languages as to be easily recognized as languages in their own right, the Ausbau languages (by 'elaboration') create their own identity by emphasizing those traits that distinguish them from languages they are closely related to (in our case, Romanian). Kloss gives the example of Czech and Slovak, Danish and Swedish, Bulgarian and Macedonian (and we can add today, Serbian, Croatian, Bosnian and Montenegrin), with a high level of intercomprehension, but which, by deliberate language planning, became different languages. The term Ausbau, warns Kloss (1967, p. 33), cannot be applied to spoken languages, in a pre-literary stage; the whole concept implies the existence of a written variant and often the creation of distinct graphical codes.

\section{Writing systems for the vernacular of the Vlachs - an overview}

The decades-long assimilation of the Serbian state directed towards the Vlach community of Eastern Serbia meant, among other things, that there was no schooling in their mother tongue, and therefore no tradition of writing the vernacular. At the end of the $19^{\text {th }}$ century, the French linguist Émile Picot (1889, p. 68) remarked that the Vlachs in Serbia had no national culture, no newspapers, no schools, while in the beginning of the $20^{\text {th }}$ century, after intensive fieldwork in the region, Vâlsan $(1913$, p. 341) stated that all publications in Romanian were destroyed at the border and that the teachers and pupils who knew Romanian were strictly forbidden to use it in school. After a few sporadic attempts in the 1940s, it is mainly in the last 20 years that actions aimed at creating writing systems for the local idiom have emerged ${ }^{6}$.

In analysing the writing systems put forward by various members of the community, three main periods can be identified. The first (1945-1948) is that of the pioneers, which encompasses the very first attempts and is characterized by a neutral, apolitical stance. We can mention here the spelling system used by Janko Simeonović in the first newspaper published in the local idiom, "Vorba noastră" (1945-1948),

tions), see Sorescu-Marinković (2012a, p. 17-36).

${ }^{3}$ For a presentation of several organizations belonging to the two factions, see Manovich (2014, p. 24-28).

${ }^{4}$ Manovich (2014, p. 1, p 48) also describes the case of a teacher who took part in her investigation and who, a few minutes after claiming that Vlach and Romanian are different languages, had a phone conversation with a person from Romania. When questioned by Manovich, the teacher claimed that she could understand Romanian, but not speak it.

${ }^{5}$ Ever since the Vlach National Council was established, in 2007, it has changed its structure several times and, accordingly, its attitude towards language.

${ }^{6}$ However, individual systems created for private use must have existed before this date, as well. 
Monica Huțanu, Annemarie Sorescu-Marinković

and in the collection of partisan poems Kaнћuкamoapja nартизағаска [Kancíkatoarja partizanjaska] (1946). The second stage (1950-1990) is characterized by a high degree of inconsistency. Several improvised transcription systems (rather than solid writing systems) were used paralelly, both by members of the community and by researchers, for private purposes or for publishing folkloric texts. As the Serbian linguist Biljana Sikimić (2003) noted, in rendering the local variety, the Vlach elites used both Cyrillic and different adapted Latin scripts (p. 87), while the folkloric texts were published using an inadequate transcription (p. 86). Many of these texts were published in the magazine "Razvitak", in "Glasnik etnografskog instituta" or "Glasnik etnografskog muzeja", most often in Cyrillic, the script preferred by the editors of these publications, but which could not render the specific phonemes of the Vlach variety (Gacović, 2016, p. 442-444; Sorescu, 2004). We will not elaborate further on this stage, as the texts published in this period are very short and heterogenous, most often traditional folkloric creations published by Vlach amateur or professional ethnologists or folklorists (double insiders, as Naumović, 1998 called them). The third period (the last 20 years) is one of the activists (Ljubiša lu Boža Kići, Paun Durlić, the "Gergina" Association, Dragomir Dragić, Slavoljub Gacović), who put forward writing systems that are framed by a certain ideology and determined by a political discourse (either independentist or reintegrationist), rather than by a scholarly one.

There are several general observations we must make before we analyse the writing systems mentioned above.

a) All writing systems put forward so far follow the phonemic principle, which is often considered the most suitable and the simplest method of writing down any unwritten idiom. This predilection towards the phonemic principle can be linked to the fact that Serbian has a shallow orthography, which requires that all sounds with functional value be graphically rendered and that this phoneme-grapheme relationship be regular, predictable and bi-univocal. It is not a coincidence that Paun Durlić, Dragomir Dragić or Ljubiša lu Boža Kići are repeatedly and directly refering to the advantages of Vuk Karadžić's spelling. Vuk Karadžić was the reformer of the Serbian language, who standardized the Serbian Cyrillic script and enforced the phonemic spelling in the first half of the $19^{\text {th }}$ century.

b) Most writing systems feature the digraphia characteristic of the Serbian language (Lüpke, 2011,p.316318; Ivković, 2013), which uses two scripts, Cyrillic and Latin. Although officially the two scripts do not have specialized functions in use, Ivković (2013) points to their diglossic specialization: Cyrillic is the official script, stated as such in the Serbian Constitution, and therefore it is used in official administrative inscriptions, texts of the Serbian Orthodox Church, textbooks, nationalist and conservative discourse, while Latin is preferred in media, advertising, on the Internet and in pro-Western liberal progressive discourse (Ivković, 2013, p. 339-341). As a rule, although they maintain the Serbian digraphia, the systems proposed for writing the Vlach vernacular do not comply with this specialization (possibly with the exception of the systems put forward by the "Gergina" Association and by Ljubiša lu Boža Kići). Moreover, preferring one of the two possible scripts to the other will always be symptomatic for the ideological position and political attitude of the proponents.

c) Even in the case of the pro-Romanian reintegrationists, the orthographic conventions are those specific to the Serbian language, whenever the phoneme is also part of the Serbian phonemic inventory (with the exception of Slavoljub Gacović). For example, the velar plosive / $\mathrm{k} /$ or the palate-alveolar fricative /3/ are represented in all systems by graphemes $\langle\mathrm{k}\rangle$ and $\langle\check{\mathrm{z}}\rangle(\langle\mathrm{K}\rangle$ and $\langle \%\rangle$ in Cyrillic, respectively), specific to Serbian, never by their $\langle\mathrm{c}\rangle$ and $\langle\mathrm{j}\rangle$ graphic equivalents found in standard Romanian. Most systems (with the exception of Paun Durlićs's and Slavoljub Gacovićs's) also adopt the orthographic Serbian conventions for writing the palatals $/ \mathrm{n} /$ and $/ K /$ (specific to the vernacular, but not to standard Romanian), using the Serbian digraphs $\langle\mathrm{nj}\rangle$ and $\langle\mathrm{lj}\rangle$ (the graphemes $\langle\mathrm{H}\rangle$ and $\langle\mathrm{b}\rangle$ in the Cyrillic script, respectively). Serbian orthography is also used for rendering the palatal affricates $/ \mathrm{t} c /$ and $/ \mathrm{d} / \mathrm{by}\left\langle\mathrm{c}^{\prime}\right\rangle$ and $\langle\mathrm{d}\rangle(\langle\hbar\rangle$ and $\langle\hbar\rangle$, respectively, in Cyrillic). Problems and differences arise, however, when it comes to writing the phonemes /a/ and / $\mathfrak{i} /$, common to all Vlach dialectal groups, phonemes that do not exist in Serbian, but are present in standard Romanian. The same is true for 
the dental affricate /cz/ and the fricatives /ç/ and / $\mathrm{j} /$, specific to the bănățeni group and also to the Banat dialects of the Romanian language, but not to Serbian or standard Romanian. The way in which those who develop writing systems choose to resolve these discrepancies is often an indication of their ideological position.

\section{The pioneers}

The first systematic attempt to render the vernacular in writing can be found in the newspaper "Vorba noastră" ${ }^{\prime}$, founded in 1945 in Zaječar and edited by Janko Simeonović. We did not have access to the first issue ${ }^{8}$, therefore we do not know whether, at least declaratively, there is a programmatic intention to create and respect certain graphical norms or whether choosing orthographic conventions was the authors' responsibility. However, regardless of the possible existence of such programmatic intentions, the system used in "Vorba noastră" is characterized by variety and inconsistency from issue to issue, and even from article to article within the same issue.

The proposed system uses the Cyrillic script, but adapts it to the phonematic realities of the local variety either by borrowing new signs, non-existent in Cyrillic, by changing the phonematic values of some letters, or by assigning additional values to certain graphemes. Thus, the central middle vowel /a/ is most frequently noted using the polyvalent grapheme $<\mathrm{a}>$ (normally used for $/ \mathrm{a} /$ ): кaнd $[$ kand], gakym [fakut]. Sometimes, in order to indicate that the phoneme is / $/$, and not $/ \mathrm{a} /$, the authors use cursive (such as in some articles from issue 3): Gracmanaм [blastamam]. However, sometimes graphic signs from standard Romanian orthography are borrowed to represent the same phoneme: 〈ă >, Hoacmpă [noastră ], că noamă [să poată] or <ầ, mpấyje [trâbuje], sezâmypâ [ljegâturâ].

We encounter the same polygraphy in the case of the closed central vowel / $\mathrm{i} /$. The most commonly

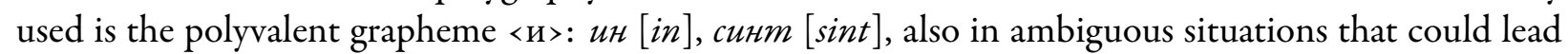
to different readings: кum [kit], кинд [kind], гинд [gind]. This phoneme is sometimes rendered by the

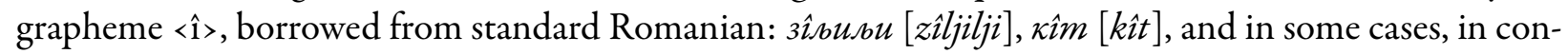
sonant groups built around a sonorant, specific for the Serbian language, it is not rendered at all: батрна [batrna], срвjаска [srbjaska], стрмба [strmba].

In the case of palatal fricatives /ç/ and / $\mathrm{j} /$, the authors generally resort to the digraphs $\langle ш j\rangle$ : numjoape [pišjoare], mjana [̌̌japa], and <жj>: asaжjeм [aljažjem]. However, sometimes, especially in the first issues,

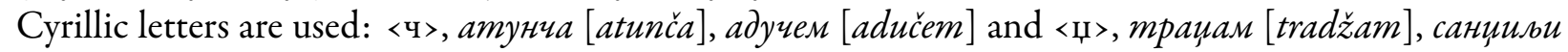
[sandžilji]. Their value is changed, because their phonetic counterpart is rarely encountered in the vernacular. It is possible that Serbian reading habitudes, as well as the existence in the vernacular of some words borrowed from Serbian and written as such (see, for example, no. 21, p. 4: часовник [ćasovnik]), led to the wide spread of digraphs at the expense of the letters with changed value.

An interesting situation arises in the case of the dental affricate / $\mathrm{d} /$, which is not graphically rendered in the pages we analysed. The generalized use of the grapheme $\langle 3\rangle$ (which represents the phoneme $/ z /$ ), including in cases such as зuka [zika], acmas [astaz], suggests that it is either a deliberate choice of a

\footnotetext{
${ }^{7}$ A previous attempt can be considered Cartea Românului din Timoc, published in Bucharest in 1941 by the Royal Cultural Foundation "King Mihai I". The volume comprises different texts (prayers, patriotic poems, classical literary texts like the poem Doina by Mihai Eminescu or the fragment Țara. Poporul from România pitorească by Al. Vlahuță), which are printed on three columns. In the first column, the texts are written in standard Romanian, in the second one they are transcribed using "the Serbian alphabet" (Cyrillic), and in the third one, using "the Croatian alphabet" (Latin). The volume is not, therefore, an attempt to graphically represent this archaic variety of Romanian, but to equate the graphemes from standard Romanian with Cyrillic or Latin graphemes, while observing the spelling conventions of the Serbian language. Although the volume is not accompanied by a statement of purpose or by the principles that guide it, it can be assumed that it was meant to awaken the latent national consciousness in this region, as the choice of texts seems to indicate. Likewise, it seems that for a short period of time, the weekly "Nădejdea”, a journal published in Romanian in Vršac between 1927 and 1944, also had a Cyrillic edition, distributed in Eastern Serbia (cf. Gacović, 2016, p. 440).

${ }^{8}$ The issues we analysed (year I, no. 3, first page; year II, no. 10 and no. 21) can be found on Paun Durlićs web page (www.paundurlic.com/forum.vlasi.srbije).
} 
Monica Huțanu, Annemarie Sorescu-Marinković

polyvalent grapheme, or, more likely, a dialectal feature absent from the phonetic repertoire of the editor or authors.

The system described above is also used in the collection of partisan poems called Kathukamoapja napmuзағаacka [Kancikatoarja partizanjaska], published in 1946 by Janko Simeonović (signing J. lu Moana Simeonović), the editor of the newspaper "Vorba noastră". Orthographic equivalents are generally the same, except that the diversity of the solutions is even more obvious, since this is a 28-page-book, with a single author. For example, in the first text of the collection, Канд је Tито командант [Kand je Tito komandant], the word comandant is written twice like in the title (командaнm [komandant]), six times комӑнданm [komăndant], and once комаิнданm [komândant].

After "Vorba noastră" was discontinued (in 1948), writing in the vernacular became an isolated and private matter. Only in the last 20 years can we talk about new attempts, more or less official, of graphically rendering the vernacular, which are usually accompanied by theoretical observations, generally ideologically loaded, according to the pro-Romanian and pro-Vlach attitudes of the proposers.

\section{The reintegrationists}

\subsection{Paun Es Durlić}

The best known representative of the reintegrationists is probably Paun Es Durlić from Majdanpek, ethnologist, who in the last decade developed an online dictionary of his native idiom (Sorescu-Marinković, 2012b). Durlićs ideas are reported on his website, www.paundurlic.com, which has lately become the meeting space and also the "battlefield" of the two opposing groups.

The spelling system proposed by Paun Es Durlić in Compendiul pentru introducerea limbii rumînești in școlile primare în Serbia răsăriteană is part of an educational framework for teaching the vernacular in primary schools, with the aim of stopping the linguistic assimilation (the situation is "catastrophic", says the author) and of helping children learn standard Romanian (which community members perceive as a foreign language), in addition to their own local idiom. The proposed model has two stages: in the first stage (the first four grades of primary school), pupils would learn to speak and write only in vernacular (in rumin'eascăas, as the author calls it), while in the second stage (from the $5^{\text {th }}$ until the $8^{\text {th }}$ grade), pupils would learn standard Romanian, partly as a foreign language, in addition to their own variety (Durlić, 2011, p. 3-4).

Regarding the spelling system, the author suggests using both scripts, the phonetic principle and the "satellite method" (Durlić, 2011, p. 4): the rumînesc Cyrillic script will be studied in the $2^{\text {nd }}$ grade, after the children have already learnt the Serbian Cyrillic script in the $1^{\text {st }}$ grade, while the rumin'esc Latin script will be taught in the $3^{\text {rd }}$ grade, after the Serbian Latin one, studied in the $2^{\text {nd }}$ grade. Even if he does not offer details about the technical aspects of his spelling system, because "first a group of experts must investigate it thoroughly and set its final form” (Durlić, 2011, p. 5), Paun Es Durlić puts forth some spelling rules for writing the vernacular. For the phonemes that do not exist in Serbian, the author introduces, in both scripts, graphemes borrowed from the phonetic alphabet created by Romanian dialectologists and used in ALR (the Romanian Linguistic Atlas): the vowels /ə/ and /ì / are rendered by $<\breve{a}\rangle$ and $\langle\hat{i}>$, respectively, the fricatives $/ c ̧ /$ and $/ \mathrm{j} /$ by $\langle\dot{s}\rangle$ and $\langle\dot{z}\rangle$, respectively, and the affricate $/ \mathrm{d} z /$ by $\langle\underset{d}{d}\rangle$. The author's preference for the ALR conventions can be accounted for by his ideological position in regard with the relationship between the local dialect and the Romanian language: in his opinion, the local vernacular can be considered a language only ethno-historically; linguistically speaking, it is just varieties of the dialects of the Romanian language (Durlić, 2011, p. 1, emphasis in original), therefore he views the system used by Romanian linguists for dialectal transcription as the most appropriate. At the same time, the familiarization of pupils with the ALR system will help them read dialectal texts collected in Romania, especially in Banat and Oltenia, which will fill the "huge gap that exists because such a material has not been collected on time in the Serbian territories where they live" (Durlić, 2011, p. 4) and, presumably, will reveal the similarity between the language spoken by the pupils and the Romanian dialects. Lastly, 
the signs $\langle\breve{a}\rangle$ and $<\hat{\imath}>$ are also found in standard Romanian spelling, which will help when learning the standard Romanian alphabet.

The author's desire to create a "transitional orthography" (Sebba, 2007, p. 76-79) to standard Romanian is also obvious from a few spelling rules the author does not explicitly mention in the Compendium, but which appear in the presentation of the script used in the on-line dictionary ${ }^{9}$, as well as in a few sentences written in vernacular in the Compendium. Thus, in order to render the fricative $/ \mathrm{J} /$ and the affricate /s/, the author uses the graphemes $\langle s$, and $\langle t$,$\rangle , respectively, specific to the orthography of$ Romanian. Also, for rendering the palatals $/ \mathrm{n} /$ and $/ K /$ in the Latin alphabet, the author does not use the Serbian digraphs $\langle\mathrm{nj}\rangle$ and $\langle\mathrm{lj}\rangle$, but takes the grapheme $\langle\mathrm{n}$ ' $\rangle$ from the ALR system, as well as $\langle$ l, $\rangle$ grapheme adapted from the IPA equivalent used in the ALR tables for palatalized $l^{10}$, not for palatal $l$. In the same way, the author does not use $\langle j>$, in the Latin script, for rendering the semivowel in diphtongs (although he keeps it in the Cyrillic script, concurring with the Serbian conventions), but $\langle\bar{i}\rangle$ (again, an IPA symbol, not the one used by Romanian dialectologists). The author himself states that, when creating a transcription system for the words in his dictionary, he paid a special attention to the Romanian orthographic tradition (see the site), which coincides with the pro-Romanian ideological position of the author. Nevertheless, we must notice that the orthographic solutions proposed by Durlić have largely changed throughout time: the first Vlach folkloric texts he published in the 1980s were only rendered in the Serbian Latin script (Durlić, 1982); after this, the author opted for a modified version of the Cyrillic script (Durlić, 1987), and in the end, he came back to the Serbian Latin script, but changed it so as to encompass the sounds characteristic to the Vlachs' vernacular (Durlić, 2001).

\subsection{Dragomir Dragić}

Dragomir Dragić from Bor, engineer by formation, is one of the most active members of the Vlach community. He is involved in the political debates surrounding this archaic variety of Romanian, but is also concerned with linguistic issues: since 2004, he has taken part in linguistic investigations in Eastern Serbia, together with the dialectologists from the "Sextil Pușcariu" Institute of Linguistics and Literary History in Cluj-Napoca. His ideas about orthography are mainly presented in the chapter Pismenost kod Vlaha, published in the volume Istraživanje zaturene istine o Vlasima ${ }^{11}$ (2007) and are exemplified in a collection of nursery rhymes, called Pră valja Kăluculuj (Jović Kolerović et al., 2014). The collection itself is accompanied by a prologue about writing down the Vlachs' vernacular, in which the author repeats some of his previous ideas.

In the author's view, the only appropriate script for rendering the vernacular is Latin. The Latin script is the original one for all the Romanized people: all the "Vlachs"-both North Vlachs (Romanians), and South Vlachs (Aromanians) - initially used the Latin alphabet, to which they returned in the end, after centuries of using the Cyrillic or Greek one. The "middle Vlachs" (of Eastern Serbia) cannot take another path; any attempt to impose other script than the Latin one is strongly connected to the "mental pollution" and political pressure on the Vlachs (Dragić, 2007, p. 28). Involving the linguists is, in Dragićs opinion, an important step towards clarifying the contradictory interpretations given to one and the same reality.

Although he understands the attraction towards the Cyrillic script, Dragić rejects the systems put forward by other members of the community, as they "hide the Romance character of the language", "are a completely wrong approach", and he accuses the proponents of hypocrisy and the wish to achieve their goals by any means (Dragić, 2007, p. 29-30). Only by putting the local idiom in a Romance context and transcribing it using the Latin script can the linguistic similarity and distance be identified and the "prototypic model" (Serb. pramodel) of the words determined (Jović Kolerović et al., 2014, p. 96).

In order for this "prototypic model" to be identified, all the texts in Pră valja Kăluculuj are written

\footnotetext{
${ }^{9}$ See www.paundurlic.com/vlaski.recnik/sound.php.

${ }^{10}$ The IPA symbol /l/, used in the ALR system and borrowed by Paun Durlić, is today obsolete; nowadays, IPA uses a superscripted $j$ for palatalized sounds (see www.internationalphoneticassociation.org/content/full-ipa-chart).

${ }^{11}$ The texts are written in Serbian, so the terms Vlah, Vlasi do not have an ideological connotation.
} 
Monica Huțanu, Annemarie Sorescu-Marinković

three times. The first variant, labelled by the author DIAL ${ }^{12}$, is the dialectal transcription, the second one, labelled IPA DIAL, is the transcription of the same text using the IPA symbols (in fact, the ALR symbols), while in the last one, labelled LATIN COR, the "alterations and palatalizations" are removed and thus the "prototypic model", the Latin root (Serb. latinski koren), is identified. For example, the title of the volume in the three variants reads: Pră valja Kăluculuj (DIAL), Pră valea Căluțului (IPA DIAL), Pe valea Căluţului (LATIN COR).

Although he does not explain what he means by the "Latin root", it is clear that Dragić refers to the standard Romanian equivalent, or at least to an equivalent graphically rendered like in standard Romanian. Dragićs system can only be taken as a whole, in all three aspects at once, because Dragićs intention is not so much to create a writing system for the local variety, but rather to prove the Romanian origin of this variety. His system is not just a means for writing the vernacular, but has a symbolic value for recovering the history and identity of the Vlach community.

\subsection{Slavoljub Gacović}

Another prominent member of the community is Slavoljub Gacović, a historian by formation, who wrote a $\mathrm{PhD}$ thesis on the history of the Vlach community in Eastern Serbia and defended it at the University of Bucharest. In his most recent work, Od povlašenih Srba do vlaškog jezika. O poreklu i postojbini, o seobama, o srbizaciji i asimilaciji, o maternjem jeziku i o popisima Rumuna (Vlaha) istočne Srbije (which is the first part of the fifth volume of an extensive study dedicated to the history of the community), Gacović addresses, from a reintegrationist ideological perspective, the orthographic rendering of the vernacular, among other things.

After reviewing some of the first empirical, unsystematic attempts at writing the local variety (a letter from 1838, sent by the inhabitants of Tekija to prince Miloš, a manuscript from the $19^{\text {th }}$ century, belonging to doctor Stevan Mačaj), Gacović analyses the systems used by the linguists, ethnologists and geographers who dealt throughout time with the community's language and traditions (Gustav Weigand, Tihomir Đorđević, St. Romanski, Marinko Stanojević, Jovan Đokić, Emil Petrovici) or who collected and published folkloric texts (Slobodan Zečević, Dragan Stojanjelović, Dragoslav Dević, Nikola F. Pavković, Živka Romelić) (see Gacović, 2016, p. 429-446). The only system Gacović approves is the one used by the Romanian linguist Emil Petrovici; he finds "unsuitable" all the other means of rendering the vernacular, for different reasons, such as: most of the systems use the Cyrillic script and the conventions of the Serbian orthography, which results in the occurrence of multiple polyphonic graphemes; the proposed writing systems are not suitable for rendering the local speeches, so they hinder their studying from a dialectological perspective; the compilers' lack of knowledge of the language leads to errors in the reproduction of the folkloric texts, which can make them useless. The more recent orthographic systems (for example, those put forward by Paun Es Durlić throughout the time or the official system of the "Gergina" Association) are also described in detail and rejected: Durlićs for not abiding to the "APHI standard", "Gergina"'s for being elaborated from an independentist ideological perspective (Gacović, 2016, p. 446-460, passim).

In the end, Gacović advances his own system of rendering the vernacular, one in which the orthographic conventions are not those specific to the Serbian orthography anymore, but are based on the "APHI [=IPA] standard" (Gacović, 2016, p. 460-461), which ensures that any dialectal resource would be available to all interested Romanists (Gacović, 2016, p. 455). Just like in the case of the systems put forward by Durlić and Dragić, the "APHI [=IPA] standard" refers again to the ALR system used by Romanian dialectologists, which is however fully complied with-at least declaratively, as the author does not offer any example of applying his writing system. The total rejection of the Serbian orthographic conventions, as well as the appeal to the ALR system reflect and confirm the pro-Romanian ideological stance of the author.

\footnotetext{
${ }^{12}$ The capitals belongs to the author of the system.
} 


\section{The independentists}

\subsection{Ljubiša lu Boža Kići}

In a few publications printed between 2004 and 2015 (a Vlach-Serbian dictionary, the first translation of The Gospels in Vlach, several collections of Vlach nursery rhymes and stories), Ljubiša lu Boža Kići (the Vlach name of Ljubiša Niculović), from the village Tanda, near Bor, puts forward a writing system called влаољица [vlaoljica] or влахољищa [vlaboljica]. These two terms, both derived from vlaška círilica [Vlach Cyrillic script], are used in free variation. In reality, there are several variants of a writing system ${ }^{13}$ that uses the Serbian Cyrillic script, enriched with several graphemes meant to render the phonemes that do not exist in Serbian.

Besides the term вла $(x)$ osuuga [vla(b)oljica], Ljubiša lu Boža Kići is also the author of other lexical creations, meant to clarify the confusions that the Serbian terms Rumun or rumunski [Romanian] might generate. Thus, in his dictionary published in 2004, he notices that, when the members of the Vlach community speak in their mother tongue, they never call themselves vlahi, but rumâni. By this, it should be understood that they speak this variety of Romanian, not that they are Romanian citizens. To avoid such a confusion, he suggests using the terms Bларумӥн [vlarumün] ${ }^{14}$ and вларумӥнеск [vlarumünesk] to refer to "rumânii ai noștri" ["our Romanians"] and their language (2004, p. 117). However, in the same text, published again in 2011, he replaces these terms with Bracu [Vlasi] and влawкu [vlaški]. In the prefaces of the volumes from 2010b and 2011, Ljubiša lu Boža Kići introduces the terms Poмâu [român] and рома̂нскu [românski] (which do not exist in Serbian, which uses Rumun and rumunski) to label everything connected to Romanians and the language spoken in Romania.

The obvious concern to distinguish the members of the community from Romanians in Romania and to distance their language from the one spoken in Romania is also reflected in the arguments the author uses to reject the Latin script. By adopting the Cyrillic script for writing down their mother tongue, the Vlachs will use what they already know. The Cyrillic script is a "guarantee against Romanianization" (lu Boža Kići, 2004, p. 118), and vla (b)oljica will prove that Vlachs do not have to become Romanians in order to be able to read and write in their own language (lu Boža Kići, 2010b, p. iii ${ }^{15}$ ). Although the official Romanian system, using the Latin script, is idealized by some and considered a measure of European values, it becomes, in the author's opinion, a means of eliminating the Vlach language: accepting the Romanian [românski] alphabet would lead to accepting the Romanian orthography, grammar, syntax; textbooks would have to be brought from Bucharest, and children would have to learn a completely new writing system; the dictionary of the Romanian language, replete with German and French words, would be used for modernizing the language, and this would lead, in time, to isolating the entire Vlach population that speaks the authentic Vlach language. The conclusion is that, in such a case, one could say the Vlach language does not exist, only Romanian [românskijezik] exists (lu Boža Kići, 2010b, p. iv-v). In other words, from the author's point of view, accepting the Latin script and the Romanian orthographic conventions would be tantamount to accepting being Romanian. By creating and using a new writing system, based on the Cyrillic script, members of the Vlach community would state their own identity, different from Romanian, somehow close to Serbian, but however totally distinct.

The resourcefulness of the lexical creations discussed above is also obvious in Ljubiša lu Boža Kići’s orthographic proposals. As he does not accept the Romanian Latin alphabet, he is forced to introduce signs taken from other orthographies or purposely created, which he then changes from text to text, giving the impression of a permanent work in progress.

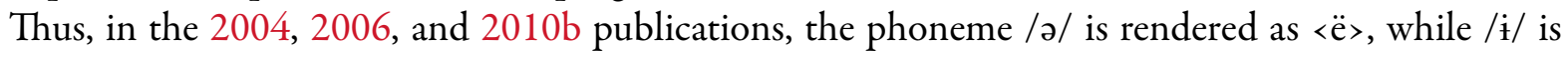

\footnotetext{
${ }^{13}$ According to the author, the first variant of vla(b)oljica dates back to 1996 (lu Boža Kići, 2015, p. 16).

${ }^{14}$ The ethnonyms are written with initial capital not only in the text written in Serbian (abiding thus to the Serbian norm), but also in the text written in the vernacular, as a result of the influence of the Serbian conventions on the proposed orthography.

${ }^{15}$ The pages of the preface of the volume from $2010 \mathrm{~b}$ are not numbered; the numbering belongs to us.
} 
rendered as $\langle\ddot{\mathrm{u}}\rangle$, therefore using letters borrowed from German (language the author refers to, alongside Russian, in the short phonetic description of the two sounds); he prefers the two graphemes because they are familiar to the Vlachs who work abroad ${ }^{16}$, so they will be easily adopted (lu Boža Kići, 2004, p. 9). In 2010a, in a first version of the volume Aлбина: повjewh pyмürвешћ [Albina: povješć rumünješ́c (posted on Paun Durlićs forum), the author proposes using the grapheme $\langle\epsilon\rangle$ for the phoneme $/ \curvearrowright /$, and $\langle\grave{n}\rangle$ for $/ \dot{\mathrm{i}} /$, but he gives up this solution in the 2011 published version and in the second edition of the dictionary (2015), where he introduces the signs $\langle\check{e}\rangle$ and $\langle\breve{u}\rangle$ for /ə/ and / $\mathbf{t} /$, respectively. In other words, $\langle\ddot{e}\rangle,\langle\epsilon\rangle$, $\langle\mathrm{e}\rangle$, respectively $\langle\ddot{\mathrm{u}}\rangle,\langle\breve{\mathrm{h}}\rangle,\langle\breve{\mathrm{u}}\rangle$, in any case not $\langle\breve{a}\rangle$ and $\langle\hat{\mathrm{i}}\rangle$, with an obvious Romanian connotation.

The diversity of solutions is also evident in the case of the homorganic pair /ç/ $-/ \mathrm{j} /$. In the 2004, 2006 , and 2010b volumes, the author uses a grapheme he himself created to render /ç/, by combining two characters from the Latin alphabet. The grapheme $\langle\mathrm{rt}\rangle$ (capital $<\mathrm{rI}>$ ) is the reversed, "mirrored" version of the Serbian grapheme $\langle\hbar\rangle$. Thus, it is supposed to be suitable both for the pronounciation of the ungureni and of the țarani, who will recognize the $\langle\hbar\rangle$ and pronounce it as $/ \mathrm{t} c /$, as it is specific to their phonetic repertoire (lu Boža Kići, 2004, p. 9). Later, in the two versions of the volume Албина: повјешћ румйњешћ (2010a and 2011) and in the second edition of the dictionary (2015), Ljubiša lu Boža Kići abandons the composed grapheme $\langle\mathrm{rt}\rangle$ for $\langle\varphi\rangle$, which is also a reversed $\langle\hbar\rangle$. As for its voiced pair $/ \mathrm{j} /$, in the 2004 and 2006 volumes the author proposes the use of $\langle\mathrm{w}\rangle$, which he drops out in all the following publications in favour of graphemes taken from the Cyrillic script: $\langle\AA \backslash$ in the two systems from 2010, $\langle\breve{\mathscr{K}}\rangle$ in the 2011 and 2015 systems. The only phoneme which has a relatively consistent rendering is the dental affricate /dz/, written with the help of the digraphs $\langle\mathrm{dz}>$ (in 2004 and 2006) and < $3>$ (probably felt as "more Cyrillic") in all the following volumes.

In the second edition of the Vlach-Romanian dictionary, published in 2015, Ljubiša lu Boža Kići puts forth a Latin script version of his writing system, which he terms laboljica. This late acknowledgement of the Latin script is accompanied, in a 2011 intervention on Paun Durlićs forum ${ }^{17}$, by the statement "The Vlachs must write, not debate". The author thinks vla(b)oljica is necessary for those Vlachs who still live in the countryside and work the land, while laboljica is created specifically for the Vlachs abroad and their children. The author keeps the graphemes $\langle\dot{e}\rangle$ and $\left\langle\mathrm{d}_{3}\right\rangle$ from the last versions of his Cyrillic system, but introduces three more: $\langle\hat{\mathrm{l}}>$ for the phoneme $/ \dot{\mathrm{i}} /,\langle\dot{\mathrm{z}}\rangle$ for $/ \mathrm{j} /$, and $\langle\hat{c}\rangle$ for $/ c ̧ /$.

Apart from the cumbersome reading, inventing signs for the phonemes characteristic of the vernacular also has the disadvantage of missing "interlinguality" (Sebba, 2007, p. 162-163). Sebba notices that speakers of a language always know something, more or less, about other languages and their orthographies and can use this knowledge in different ways. Obstinately avoiding any association with the Romanian spoken (and written) in Romania and inventing or adopting letters from other languages (German, Russian) excludes those Vlachs who are familiar with the Romanian orthographic conventions, which is a clear indicator of Ljubiša lu Boža Kići’s ideological stance.

\subsection{The "Gergina" Association}

The "Gergina" Association for the conservation of the tradition, language, culture, customs and identity of the Vlachs is an NGO founded in Negotin in December 2009. Its objectives are the protection and conservation of the cultural and linguistic heritage of the Vlachs living in Eastern Serbia and other regions ${ }^{18}$. In the last five years, "Gergina" undertook various actions of linguistic planning, which materialized in a writing system for the Vlach vernacular, a Vlach grammar and a textbook, as well as in introducing Vlach language classes in several schools (see Manovich, 2014; Huțanu \& Sorescu-Marinković, 2015).

In 2012, the writing system proposed by "Gergina" was officially adopted by the Vlach National Council, an institution which in Serbia has total control on issues regarding the education, culture and

\footnotetext{
${ }^{16}$ In spite of being a relatively conservative and traditional community, the Vlachs of Eastern Serbia have been very mobile starting with the 1950s. They had a significant share in the number of Yugoslav labour migrants abroad; some researchers claim that in the 1960s and 1970s their number was even four times larger than that of the Serbs (Schierup \& Ålund, 1986).

${ }^{17}$ See www.paundurlic.com/forum.vlasi.srbije/index.php?topic $=1121.0$.

${ }^{18}$ See www.gergina.org.rs/o-nama/udruzenje.
} 
mass-media in the language of this minority. The Vlach National Council has as one of its objectives the standardization and codification of writing in Vlach and the introduction of the Vlach language in official use $^{19}$, both of which are the responsibility of the Comission for the Official Use of Language and Writing of VNC. After being officially adopted, the writing system was used in the first Vlach textbook, Byopбa uй кyлmypa влаха [Vuorba șî kultura vlaha], published in 2014 and authored by Milena Golubović. The title highlights the independentist ideological position from which the textbook was elaborated and, consequently, the official position of the two associations involved in the linguistic planning: the use in vernacular of the exonym vlah (and not rumin) for ethnic self-identification is meant to distance the variety spoken in Eastern Serbia from Romanian and thus to legitimize it. Moreover, granting official status to the system is itself symbolic; as Alexandra Jaffe (2000, p. 505-506) notes, it is not enough for a new writing system to be created, it is essential that this writing system (as a mechanism of creating linguistic boundaries) have prescriptive power and authority, similar to the orthographies of dominant languages.

The graphic system created by "Gergina" and officialized by the Vlach National Council acknowledges the use of both scripts, Latin and Cyrillic. Cyrillic has been used by the Vlachs ever since they started writing (1392, since, according to the authors, the first document in Cyrillic-The Manuscript of Leud (sic) - dates), and therefore has the advantage of tradition and age. Nevertheless, the authors consider the introduction of the Latin script a logical choice in the modern era, when its different variants are used all over the world, especially in view of the fact that many Vlachs are today "inhabitants of Europe" 20 . The Latin script has thus international character and breathes modernity.

For the phonemes absent in the vernacular, the authors introduce special signs, generally different in the two scripts, but relatively corresponding to one another: the Latin grapheme has a Cyrillic equivalent, accompanied by a diacritical mark which is identical or at least similar to the one used in the Latin alphabet. In both scripts, the vowel /ə/ is written $<\breve{a}\rangle$, like in standard Romanian. The grapheme $\langle\hat{\imath}>$ is also borrowed from standard Romanian to render in the Latin script the phoneme / $\mathfrak{i} /$, which is written $/ \breve{\mathrm{u}} /$ in the Vlach Cyrillic version. The affricate / $\mathrm{d} /$ is rendered in the Latin version with the help of the digraph $\langle\mathrm{dz}\rangle$, and in Cyrillic by its equivalent, $\left\langle\mathrm{A}_{3}\right\rangle$. The authors propose the graphemes $\langle\dot{s}\rangle$ and $\langle\dot{\mathrm{z}}\rangle$ for the fricatives /ç/ and / $j /$ in the Latin version, and <ய́< and <ж́> in the Cyrillic one.

The Latin version of the official writing system is used in bilingual texts published online on the site of the newspaper "Reč naroda" from Braničevo, as part of a project financed by the Ministry of Culture and Information of the Republic of Serbia, called "Projekat 'Ponosni Vlasi - interkulturalno Braničevo' / Projektu 'Vlasi maruoš - Branjičeva întră kulturj”'”21. The texts published here address the Vlachs' origin, language, traditions, as well as the activities of the Vlach National Council, and are authored in Serbian by Andrijana Maksimović and translated into Vlach by Slobodan Golubović. A quick look at these texts reveals several problems and inconsistencies, caused (among other things) by the rather superficial description of the writing system.

Thus, the authors' statement that their writing system follows the "one grapheme - one phoneme" approach should have been accompanied by a description of the phonematic structure of the local variety. Without one, those who apply the system are faced with the variety that characterizes speech, which leads to co-ocurring spellings, such as: sî ajbe - să ajbje (several lines apart), njeagră - njagră (in the same text) or njišce - nišće. Another issue any official alphabet should tackle is the criteria for establishing word boundaries, and, accordingly, what constitutes a word (Lüpke, 2011, p. 314). The absence of such criteria explains variations like măj batrînă - măjbatrînă, măj bun - măjbun, a dîpraurmă - a dìpraurmă. Furthermore, consistency is needed when it comes to the grapheme-phoneme correspondence: there are situations when the spelling is influenced by Serbian orthographic conventions, such as măjnainče (written

\footnotetext{
${ }^{19}$ See www.nacionalnisavetvlaha.rs/onamaciljevi.html.

${ }^{20}$ See www.gergina.org.rs/index.php/vlasko-pismo.

${ }^{21}$ See recnaroda.co.rs/kategorije/ponosni-vlasi-vlasi-maruos. Recently, the system also started to be used on the website of the "Matica Vlaha" / "Matka Vlahilor" Association, which has a Vlach version: matkavlahilor.org.rs/vl.
} 
with $\langle\dot{c}>$ instead of $\langle\dot{c}>$ ) or prstă (instead of prîstă, the more frequent variant).

One more problem of the official writing system became obvious when writing this very paper. The graphemes <ய́> and <ж́>, proposed by "Gergina” for writing in Cyrillic the fricatives /ç/ and $/ \mathrm{j} /$, are not included in the Unicode standard ${ }^{22}$, therefore they are not part of the inventory offered by computers. To write them, we had to use additional diacritics, which doubles the time and effort needed to write a grapheme. Lüpke (2011, p. 333-334) warns that the usefulness and applicability of an orthographic system are strongly connected to the way in which its letters can be written using the computer keyboard, and selecting non-standardized characters is "short-sighted". Obviously, it is possible to create special fonts and to try to introduce them in the Unicode standard, but it can be a lengthy process, which does not guarantee the acceptance of the new characters by this standard.

\section{Conclusions}

The current paper addressed, from a sociolinguistic perspective, the problems of creating an orthography for an unwritten idiom. Although the first systematic attempts at writing the vernacular date from the 1940s (especially by means of the publication "Vorba noastră" and the collection of partisan poems Kancikatoarja partizanjaska), it is the last 20 years that stand out by the number and significance of attempts at graphically rendering the variety of Romanian spoken in Eastern Serbia. While the writing system used in "Vorba noastră" is known to all the proponents, none of them take this system as their starting point, neither explicitly nor implicitly. Conceivably as a result of the inconsistencies inherent to beginnings, the first writing system creating for writing Vlach in Eastern Serbia is always mentioned, but never used.

Moreover, although the Vlach writing system has been granted official status and the decision of standardizing the Vlach language has been published in the Official Gazette of Serbia in October 2015, writing in the vernacular is still in what Rehg (2004, p. 510) labelled the laissez-faire stage: even if the members of the community can write, there is no general agreement as to how they should write or even what graphemes to use. For now, the Vlachs of Eastern Serbia do not have a single, unitary orthography, as there is no unanimously accepted authority. Furthermore, apart from the arguments, disagreements and frictions among the proponents of different systems, there is no real debate on the writing systems. At this moment, writing in the vernacular is a rare and unusual thing for the Vlachs: books in vernacular are few and marginal, usually published at the expense of the author, there are no periodical publication, the Vlach language classes have only started, and even the proponents of the writing systems use Serbian for the texts which accompany, justify or explain the systems and their ideological position. The vernacular is mainly used in unregulated spaces (Sebba, 2007, p. 44): on the Internet (on the personal sites of the engaged authors, Facebook pages and profiles etc.), in private texts, for personal use, and lately for funeral inscriptions (Huțanu \& Sorescu-Marinković, 2016).

The orthographic debates among the Vlachs of Eastern Serbia reveal the importance of social or political factors in creating and imposing a writing system. Whether it serves to establish similarity to or difference from other codes, the choice of a specific orthography reflects and, at the same time, creates linguistic identity. In the Vlachs' case, the two factions, reintegrationist and independentist, create writing systems which reflect their dominant ideology, but which, at the same time, are meant to legitimize their ideological position and to give it authority.

\section{Bibliography}

\section{A. References}

Constante, C. (1929). Românii din Valea Timocului și a Moravei, in Constante \& Golopenția, 2008, vol. I, p. $215-242$.

Constante, C. \& Golopenția, A. (2008). Românii din Timoc, culegere de izvoare îngrijită de C. Constante și A. Golopenția; ediție de N. Mușat; prefață de O. Hedeșan; postfață de S. Golopenția, Editura Marineasa, Timișoara (ediția I: prefață de Dr. S. Manuilă și o introducere de E. Bucuța, vol. I-III, Imprimeria Institutului Statistic, București, s.a).

\footnotetext{
${ }^{22}$ See www.unicode.org/charts/PDF/U0400.pdf.
} 
Coulmas, F. (2009). Evaluating Merit - The Evolution of Writing Reconsidered, in "Writing Systems Research", vol. 1, no. 1, p. 5-17, Crossref.

Dragić, D. (2007). Istraživanje zaturene istine o Vlasima, I deo, Forum za Kulturu Vlaha, Bor.

Durlić, P. (1982). Đurdevdan u Rudnoj Glavi (grada), in “Zbornik radova Muzeja rudarstva i metalurgije u Boru”, knj. 2, Bor, p. 197-199.

Durlić, Р. (1987). Басме из Горғег Пореча, in “Развитак”, бр. 4-5, p. 105-118.

Durlić, P. (2001). Rokovnik za 2002. godinu sa etno-kalendarom Vlaha istočne Srbije.

Durlić, P. Es (2011). Compendiu pentru introducerea limbii rumîn'ești în școlile primare în Serbia răsăriteană, [online].

Eira, C. (1998). Authority and Discourse: Towards a Model for Orthography Selection, in "Written Language \& Literacy", vol. 1, no. 2, p. 171-224, Crossref.

Florea, S. (2015). Avataruri ale identității - discurs public și parcurs intim. Studiu de caz - românofonii din Serbia de răsărit (teză de doctorat susținută în 2015 la SNSPA București, coordonator Vintilă Mihăilescu).

Gacović, S. (2016). Od povlašenih Srba do vlaškog jezika. O poreklu i postojbini, o seobama, o srbizaciji i asimilaciji, o maternjem jeziku i o popisima Rumuna (Vlaha) istočne Srbije, Fabula Nostra, Beograd, Književno-izdavačko društvo Leksika, Negotin, 2016.

Golubović, М. (2014). Вуорба шй култура Влаха: Уибеник из предмета влашки говор са елементима националне културе за први разред основне школе, Zavod za udžbenike, Beograd, Nacionalni Savet Vlaha, Petrovac na Mlavi.

Huțanu, M. \& Sorescu-Marinković, A. (2015). Graiul vlah în școlile din Serbia răsăriteană: provocări și perspective, in "Philologica Jassyensia”, vol XI, no. 2, p. 201-211.

Huțanu, M. \& Sorescu-Marinković, A. (2016). Novi nadgrobni natpisi na vlaškom u istočnoj Srbiji, in “Folkloristika”, 1/2, p. 2742, [online].

Irvine, J. T. \& Gal, S. (2000). Language Ideology and Linguistic Differentiation, in Kroskrity, P.V. (ed.), Regimes of Language: Ideologies, Polities, and Identities, School of American Research Press, Santa Fe, p. 35-84, [online].

Ivković, D. (2013). Pragmatics Meets Ideology. Digraphia and Non-Standard Orthographic Practices in Serbian Online News Forums, in "Journal of Language and Politics", vol. 12, no. 3, p. 335-356, Crossref.

Jaffe, A. (2000). Introduction: Non-Standard Orthography and Non-Standard Speech, in "Journal of Sociolinguistics", vol. 4, no. 4, p. 497-513, Crossref.

Jović Kolerović, S., Dragić, D., Paunjelović, F., Stojanjelović, D. \& Mitrović Mitra, V. (2014). Pră valja Kăluculuj / Pră valea Căluţului / Pe valea Căluţului: Dečje vlaške pesme, Štamparija Stojadinović, Petrovac na Mlavi.

Kloss, H. (1967). 'Abstand languages' and 'Ausbau languages', in “Anthropological Linguistics", vol. 9, no. 7, p. 29-41, [online]. lu Boža Kići, Lj. (2004). Влашко-српски речник. Вларумӥнеск-србјеск ворбарjу, Grafomed, Bor.

lu Boža Kići, Lj. (2006). Јевангеља сфӥнтё, Grafomed, Bor.

lu Boža Kići, Lj. (2010a). Албина: повјешћ румйъешћ = влашке приповетке, [excerpt available online].

lu Boža Kići, Lj. (2010b). Влашке песме, Grafomed, Bor.

lu Boža Kići, Lj. (2011). Албина: повјешћ румйтешћ = влашке приповетке (допуњено издағе), Nacionalni Savet Vlaha, Negotin, Štamparija Stojadinović, Petrovac.

lu Boža Kići, Lj. (2015). Влашко-српски речник. Вларумӥнеск-србјеск ворбарју (2. допуњено изА.), Тегсіја, Bоr.

Lüpke, F. (2011). Orthography Development, in Austin, P.K. \& Sallabank, J. (eds), The Cambridge Handbook of Endangered Languages, Cambridge University Press, p. 312-336, [online].

Manovich, D. (2014). Folk Linguistics and Politicized Language: the Introduction of Minority Language Education for the Vlachs in Serbia (submitted to Central European University Nationalism Studies Program in partial fulfilment of the requirements for the degree of Master of Arts), Budapest, [online].

Meteș, Ș. (1971). Emigrări românești din Transilvania în secolele XIII-XX. (Cercetări de demografie istorică), Editura Științifică, București.

Naumović, S. (1998). Romanticists or Double Insiders? An Essay on the Origins of Ideologised Discourses in Balkan Ethnology, in "Ethnologia Balkanica", vol. 2, p. 101-120, [online].

Pătruț, I. (1942). Folklor de la Românii din Sîrbia, in "Anuarul arhivei de folklor”, VI, p. 329-384.

Petrovici, E. (1942). Note de folklor de la Romînii din Valea Mlavei (Sîrbia), in “Anuarul arhivei de folklor”, VI, p. 43-75.

Picot, É. (1889). Românii din Timoc, traducere din limba franceză de C. Constante, in Constante \& Golopenția, 2008, vol. I, p. $67-70$.

Popovici, A. (1919). Memoriul românilor din Serbia, in Constante \& Golopenția, 2008, vol. II, p. 108-122.

Priestly, T.M.S. (1992). Problems in the Creation of an Orthography: Functional Load, Interference, and Political Preferences, in "Slavic and East European Journal", vol. 36, no. 3, p. 302-316, Crossref.

Rehg, K. L. (2004). Linguists, Literacy, and the Law of Unintended Consequences, in “Oceanic Linguistics”, vol. 43, no. 2, p. 498518, [online].

Schieffelin, B.B. \& Doucet, R.C. (1994). The "Real" Haitian Creole: Ideology, Metalinguistics, and Orthographic Choice, in "American Ethnologist", vol. 21, no. 1, p. 176-200, Crossref.

Salgado, B.F. \& Monteagudo, H. (1993). The Standardization of Galician: The State of the Art, in "Portuguese Studies", vol. 9 , p. 200-213, [online]. 
Sallabank, J. (2002). Writing in an Unwritten Language: The Case of Guernsey French, in "Reading Working Papers in Linguistics", vol. 6, p. 217-244, [online].

Schierup, C.-U. \& Ålund, A. (1986). Will They Still Be Dancing? Integration and Ethnic Transformation among Yugoslav Immigrants in Scandinavia, University of Umeå, [online].

Sebba, M. (2007). Spelling and Society. The Culture and Politics of Orthography around the World, Cambridge University Press.

Sebba, M. (2015). Iconisation, Attribution and Branding in Orthography, in "Written Language \& Literacy", vol. 18, no. 2, p. 208-227, Crossref.

Sikimić, В. (2003). Полевье исследования „влахов” в северо-восточной Сербии, in Соволев, А.Н. \& Русаков, А.Ю. (еds), Актуальныц вопросы балканского языкознания, Наука, Санкт-Петербург, р. 85-96.

Sikimić, B. (2014). Romanians in Serbian Banat: Dynamic Epistemology, in Kamusella, T. \& Nomachi, M. (eds), The Multilingual Society Vojvodina. Intersecting Borders, Cultures and Identities, Slavic Research Center, Hokkaido University, Sapporo, p. 51-73, [online].

Sorescu, A. (2004). The Vlach Folk Literature - An Identity Document that Has not Been Printed Yet, in Krouжевност на језииима матина у Подунављу, Београд: Институт за книжевност и уметност, Институт за књижевност, БеограА, p. $185-193$.

Sorescu-Marinković, A. (2007). Comunități românofone din Serbia. Identitate lingvistică sau ceva mai mult?, in Botoșineanu, L. et al. (eds), Români majoritari / Români minoritari: interferențe și coabitări lingvistice, literare și etnologice, Editura Alfa, Iași, p. 863-875.

Sorescu-Marinković, A. (2012a). Românii din Timoc astăzi. Ființe mitologice, Editura Argonaut, Cluj-Napoca.

Sorescu-Marinković, A. (2012b). Vorbarǐ Ruminnesk: The Vlach on line Dictionary, in "Philologica Jassyensia", vol. VIII, no. 1, p. 47-60.

Unseth, P. (2005). Sociolinguistic Parallels between Choosing Scripts and Languages, in "Written Language \& Literacy", vol. 8, no. 1, p. 19-42, Crossref.

Unseth, P. (2008). The Sociolinguistics of Script Choice: An Introduction, in "International Journal of the Sociology of Language”, vol. 192, p. 1-4, Crossref.

Vâlsan, G. (1913). Românii din Bulgaria și Serbia, in Constante \& Golopenția, 2008, vol. I, p. 328-344.

Weigand, G. (1900). Dialectele românești ale Valabiei mici, ale Serbiei și ale Bulgariei, in Constante \& Golopenția, 2008, vol. I, p. $71-87$.

\title{
B. Websites
}

\author{
www.gergina.org.rs \\ www.internationalphoneticassociation.org \\ matkavlahilor.org.rs/vl \\ www.nacionalnisavetvlaha.rs \\ www.paundurlic.com \\ www.recnaroda.co.rs/kategorije/ponosni-vlasi-vlasi-maruos \\ www.unicode.org
}

